\title{
Field evaluation of biocontrol agents against black-foot and Petri diseases of grapevine
}

\author{
María del Pilar Martínez-Diz ${ }^{1,2}$, Emilia Díaz-Losada ${ }^{1}$, Marcos Andrés-Sodupe ${ }^{3}$, Rebeca \\ Bujanda $^{3}$, María Mercedes Maldonado-González ${ }^{3}$, Sonia Ojeda ${ }^{3}$, Amira Yacoub $^{4}$, Patrice \\ Rey $^{4}$, David Gramaje ${ }^{3}$
}

${ }^{1}$ Estación de Viticultura e Enoloxía de Galicia (AGACAL-EVEGA), Ponte San Clodio s/n 32428-Leiro-Ourense, Spain.

${ }^{2}$ Universidade da Coruña, Facultade de Ciencias, Zapateira, 15071 A Coruña, Spain.

${ }^{3}$ Instituto de Ciencias de la Vid y del Vino (ICVV), Consejo Superior de Investigaciones Científicas - Universidad de la Rioja - Gobierno de La Rioja, Ctra. LO-20 Salida 13, Finca La Grajera, 26071 Logroño, Spain.

${ }^{4}$ INRA, ISVV, UMR1065 SAVE, F-33140, Villenave d'Ornon, France.

* Correspondence to: D. Gramaje, Instituto de Ciencias de la Vid y del Vino (ICVV), Consejo Superior de Investigaciones Científicas, Universidad de la Rioja, Gobierno de La Rioja, Ctra. LO-20 Salida 13, 26007 Logroño, Spain.

E-mail: david.gramaje@icvv.es

\begin{abstract}
BACKGROUND: Black-foot and Petri diseases are the main fungal diseases associated with young grapevine decline. Two field experiments were established to evaluate the preventive effect of two potential biocontrol agents (BCAs), i.e. Streptomyces sp. E1 + R4 and Pythium oligandrum Po37, and three BCA-commercial products containing Trichoderma atroviride SC1, Trichoderma koningii TK7 and Pseudomonas fluorescens + Bacillus atrophaeus on fungal infection in grafted plants and plant growth parameters.

RESULTS: The effectiveness of some BCA in reducing the incidence and severity of both diseases was dependent on the plant part analyzed and the plant age. No single BCA application was able to control both diseases. Streptomyces sp. E1+R4 were able to reduce significantly black-foot disease infection while P. oligandrum Po37 and Trichoderma spp. were able to reduce significantly Petri disease infection. BCA treatments had no effect on the shoot weight, and root weight was significantly lower in all BCA treatments with respect to the control.
\end{abstract}

CONCLUSIONS: The combination of the disease-suppressive activity of two or more beneficial microbes in a biocontrol preparation is required to prevent infection by black-foot and Petri disease fungi in vineyards.

Keywords: Bacillus, grapevine trunk diseases, Pseudomonas, Pythium, Streptomyces, Trichoderma, Vitis vinifera $\mathrm{L}$. 


\section{INTRODUCTION}

Grapevine trunk diseases (GTDs) are one of the most damaging diseases affecting the grapevine industry in all grape-growing regions worldwide, being responsible for yield and productivity loss, and one of the main causes of an early vines death. ${ }^{1}$ Among them, black-foot and Petri diseases are the two most common GTDs affecting planting material at nurseries, newly planted vines and young vineyards ( $<5$ years old). ${ }^{2-4}$ In La Rioja (northern Spain), the annual financial cost of the replacement of death plants cv Tempranillo in due to black-foot and Petri diseases is estimated to be 7.16 million $€ /$ year. ${ }^{5}$ Field symptoms of black-foot and Petri diseases affected vines include overall stunting growth, delayed budbreak, retarded or absent sprouting, shortened internodes, chlorotic and sparse foliage with necrotic margins, leaves or entire shoots wilting, and dieback. ${ }^{3}$ However, these symptoms also resemble those associated with abiotic disorders such as spring frost, winter damage and/or nutrient deficiency. ${ }^{1}$ Characteristic symptoms of black-foot disease include dark brown and soft areas in roots and black discolouration and necrosis in the basal end of the rootstock. ${ }^{2}$ Regarding Petri disease, dissected affected vines display brown and black vascular streaking, mainly in the rootstock, and gumming that turns dark when exposed to air. ${ }^{3}$

Up to 32 species of the genera Campylocarpon, Cylindrocladiella, Dactylonectria, Ilyonectria, Neonectria, Pleiocarpon and Thelonectria have been reported to cause black-foot disease, ${ }^{1,6-8}$ Dactyonectria torresensis being the most prevalent species associated with diseased vines in Europe. ${ }^{9-11}$ These fungal species are known to be soilborne and persist as mycelium and conidia in rotten root fragments or as resting spores (chlamydospores) that can survive in the soil for extended periods of time after infected plants are removed. ${ }^{4,12}$ Apparently healthy plants placed in infested nursery soil can become infected through trunk wounds or roots, such as the incomplete callused rootstock end. ${ }^{2}$

The main fungal species associated with Petri disease is Phaeomoniella (Pa.) chlamydospora. ${ }^{13}$ However, other fungal species that have also been isolated in relatively high frequencies from Petri diseased vines are 29 species of the genus Phaeoacremonium, Pleurostoma richardsiae, and 6 Cadophora spp. ${ }^{1}$ Among those, Phaeoacremonium (Pm.) minimum and Cadophora luteo-olivacea are the most prevalent. ${ }^{13,14} \mathrm{~Pa}$. chlamydospora and Phaeoacremonium spp. can spend part of their disease cycle in soil as mycelium and conidia in infected rootstock wood, roots or pruning debris, ${ }^{15,16}$ or chlamydospores in the case of $P a$. chlamydospora. ${ }^{15}$ The presence of Cadophora spp. in soils has been recently confirmed using ITS high-throughput amplicon sequencing (HTAS) approach. ${ }^{17}$ Therefore, the main hypothesis is that these fungi could gain entry into the xylem of young plants at the nursery or newly established vineyards through root and/or basal end of the rootstock infections. In addition, they are also disseminated through the dispersion of airborne spores (conidia and/or ascospores) by rain, wind or arthropods until they land on susceptible and fresh pruning wounds. ${ }^{15}$

Presently, no curative measures are available to reduce the impact of these diseases once the vines are infected, making their management in the field difficult. Furthermore, the loss of the most effective preventative chemical products such as the banning in the early 2000 s of sodium arsenite or benzimidazoles, ${ }^{18}$ and the high current restrictions and difficulties that chemicals are facing in most countries around the world because of the risks for human health and the environment, ${ }^{19,20}$ increase even more the complexity of their control. Nowadays, the best way to handle these diseases is by using an Integrated Pest Management (IPM) strategy ${ }^{21}$ where several strategies are combined to reduce GTDs infections, such as the use of physical (e.g. hot-water treatment), biological (e.g. antagonist microorganisms) and cultural practices (e.g. crop management, irrigation, soil preparation, etc.), throughout the nursery mother blocks and newly planted vineyards. ${ }^{1}$

Investigation of BCAs able to prevent or at least reduce the development of GTDs are considered a research priority. ${ }^{1}$ In fact, over the last 10 years there has been a frantic search by 
the GTDs research community for microbial antagonists, including fungi, ${ }^{21-33}$ bacteria, ${ }^{29,34-40}$ and oomycetes. ${ }^{41,42}$ Although some of these studies provided promising findings, the results have not been consistent, observing differences in efficacy depending on the nature of the BCA, the target pathogen, application method, time of exposure to the BCA and even the grapevine cultivars and rootstocks subjected to study. In addition, most of these studies have been performed so far under in vitro laboratory, ${ }^{26,29,31,32,34-40}$ greenhouse ${ }^{29,31,32,35-37,41,42}$ or nursery ${ }^{21-}$ $25,28,33,38$ controlled conditions by using rootstock or scion cuttings.

Three Trichoderma-based biological products are currently registered in Spain for the preventive protection of pruning wounds against GTD fungi, namely Esquive ${ }^{\circledR}$ (Trichoderma atroviride I-1237), Blindar ${ }^{\circledR}$ (Trichoderma asperellum ICC012 + Trichoderma gamsii ICC080) and Vintec ${ }^{\circledR}\left(T\right.$. atroviride SC1). ${ }^{43}$ Only Vintec ${ }^{\circledR}$ has been additionally registered to control Petri disease pathogens in grapevine grafted nursery stock. ${ }^{43}$ Therefore, we propose to apply registered BCA products in Spain for control of GTD fungi both on grapevine and/or other hosts, and other potential BCAs as a preventive strategy in pre- and post-planting. The main objectives of this study were: (i) to evaluate the effectiveness of several BCA root treatments under field conditions in reducing natural infections of fungal pathogens associated with black-foot and Petri diseases over two growing seasons, and (ii) to assess the BCA root treatments influence in plant growth parameters.

\section{MATERIALS AND METHODS}

\subsection{Planting material}

One-year old grapevine grafted plants of 'Tempranillo'/110 Richter combination with uniform root distribution were obtained from a commercial nursery in Spain and used in this experiment. Roots were trimmed to $10 \mathrm{~cm}$ length and dormant plants were hot-water treated at $53^{\circ} \mathrm{C}$ for 30 min to reduce any existing infections by black-foot and Petri disease pathogens ${ }^{44,45}$ and then acclimatized for $24 \mathrm{~h}$ at $20^{\circ} \mathrm{C}$ before biological control agents (BCA) inoculation.

\subsection{Grafted plants inoculation and experimental design}

Hot-water treated plants were inoculated by dipping the roots and the basal part of the plants for $24 \mathrm{~h}$ at room temperature with 251 water suspensions of the following treatments: (T1) Streptomyces sp. E1 + R4 $\left(1.35 \times 10^{9} \mathrm{CFU} \mathrm{m}^{-1}\right)$ at $7.5 \mathrm{ml} \mathrm{l}^{-1}$, (T2) Trichoderma koningii TK7 (Condor Shield ${ }^{\circledR}$, ATENS; $1 \times 10^{9} \mathrm{CFU} \mathrm{g}^{-1}$ formulated product) at $2 \mathrm{~g} \mathrm{l}^{-1}$, (T3) T. atroviride $\mathrm{SC} 1$ (Vintec ${ }^{\circledR}$, Belchim Crop Protection; $2 \times 10^{10} \mathrm{CFU} \mathrm{g}^{-1}$ formulated product) at $2 \mathrm{~g} \mathrm{l}^{-1}$, (T4) Pseudomonas fluorescens + Bacillus atrophaeus (Stilo Cruzial ${ }^{\circledR}$, SIPCAM Iberia; $1 \times 10^{8} \mathrm{CFU}$ $\mathrm{g}^{-1}$ formulated product) at $2 \mathrm{~g} \mathrm{l}^{-1}$, (T5), Pythium oligandrum Po37 (Biovitis, France; $1.28 \times 10^{6}$ $\mathrm{CFU} \mathrm{\textrm {g } ^ { - 1 }}$ ) at $2 \mathrm{~g} \mathrm{l}^{-1}$, and (C) water as untreated control. We selected $\mathrm{T} 1$ and $\mathrm{T} 5$ due to the previously demonstrated efficacy against GTD fungi in young vines. ${ }^{38,41} \mathrm{~T} 2$ and T4 are not registered as a phytosanitary product in Spain yet. The viability of the Trichoderma conidia in the products T2 and T3 was checked to be at a minimum of $85 \%$ before the trial, as described by Pertot et al. ${ }^{28}$

Inoculated grafted plants were immediately planted in May 2017 in two field sites located in Logroño (La Rioja, Spain). Both fields were under grapevine nursery planting material rotation, which is very common in the area of study. Standard cultural practices were used in both sites during the grapevine growing season. The plant groups (40 plants) were spaced 100 $\mathrm{cm}$ from other groups, plants being $30 \mathrm{~cm}$ apart from center to center. Each field plot was $12 \mathrm{~m}$ long and included 24 rows, each with a plant group of 40 plants (960 plants per field). In both sites, the experimental design consisted of four randomized blocks, each containing a plant group (40 plants) of each treatment (160 plants per treatment), with $200 \mathrm{~cm}$ between each block. 
Plots were less than $1 \mathrm{~km}$ apart and had very similar climates. Soil samples were taken for physicochemical properties analysis as described below. A drip irrigation system was laid on the soil of each row. An additional stock of 50 grafted plants was used to check for their phytosanitary status immediately after hot-water treatment (HWT).

\subsection{GTD fungal isolation and identification}

In February 2018, once grafted plants had completed their cycle of vegetative growth and were in a dormant state, $50 \%$ of the 2 -year-old plants in each field were carefully dug out from the soil to keep the root system intact and taken back to the laboratory for immediate processing. In order to isolate black-foot and Petri disease pathogens, two plant parts were evaluated, roots and the basal ends of the rootstocks. Root necrotic sections from $2-3 \mathrm{~cm}$ near the basal end of the rootstock and wood sections of $3 \mathrm{~cm}$ length of the basal end of the rootstock were cut, washed under running tap water, surface sterilized in $33 \%$ sodium hypochlorite (commercial $40 \mathrm{~g} \mathrm{Cl} / 1$ ) for $1 \mathrm{~min}$ and rinsed twice with sterile distilled water. Five small root or xylem pieces were plated on Malt Extract Agar (MEA) supplemented with $0.35 \mathrm{gl}^{-1}$ of streptomycin sulphate (Sigma-Aldrich, St. Louis, MO, USA) (MEAS). Four MEAS plates were used per plant (two per plant part). Plates were incubated for $10-15$ days at $25^{\circ} \mathrm{C}$ in the dark and all colonies were transferred to Potato Dextrose Agar (PDA). Isolates were single-spored prior to morphological and molecular identification with the serial dilution method. ${ }^{46}$

In May 2018, the remaining 50\% of the plants in each field were drip inoculated with all treatments $(0.51$ per plant using the same inoculum concentration as described above). In February 2019, these 3-year-old plants were carefully dug out and processed for fungal isolation as described above. All planting material was washed and also assessed for undried shoot and total root weight. The disease incidence (DI) of black-foot and Petri disease pathogens was determined as the mean percentage of grafted plants that was infected by these fungi. The disease severity (DS) in infected grafted plants was determined as the mean percentage of root or wood segments (ten segments per plant each) that was colonized by these fungi. The presence of Trichoderma spp. was also recorded to provide an indication of the extent of colonization following treatment with the Trichoderma formulations (T2 and T3). The stock of 50 plants was also analysed after HWT as described before.

Fungal isolates resembling black-foot and Petri disease pathogens were identified by molecular techniques. For DNA extraction, $300 \mathrm{mg}$ of fungal mycelium and conidia from single spore isolates grown on PDA for 2 to 3 weeks at $25^{\circ} \mathrm{C}$ in the dark were scraped and homogenised twice in a Fastprep ${ }^{\circledR}-24$ tissue homogenizer (MP Biomedicals, USA). Total DNA was extracted using the E.Z.N.A. Plant Miniprep Kit (Omega Bio-tek, Doraville, USA) following manufacturer's instructions. DNA was visualized on 1\% agarose gels stained with RedSafe (iNtRON Biotechnology, Lynnwood, WA, USA). DNA was stored at $-20^{\circ} \mathrm{C}$. Blackfoot species were identified by sequencing part of the histone gene (his3) using CYLH3F and CYLH3R primers. ${ }^{47-49}$ The identification of $\mathrm{Pa}$. chlamydospora isolates was performed by analysis of the ITS region of DNA amplified using the fungal primers Pch1/Pch2. ${ }^{50} \mathrm{Pm}$. minimum and $C$. luteo-olivacea were identified by sequence analysis of the $\beta$-tubulin (tub2) using the primer pairs $\mathrm{T}^{51}$ and $\mathrm{Bt}^{2} \mathrm{~b}^{52}$ for Phaeoacremonium, and $\mathrm{BTCadF} / \mathrm{BTCadR}^{53}$ for Cadophora. Trichoderma spp. were isolated on MEAS and identified at species level by sequencing the ITS region using the universal primers ITS1F/ITS4. ${ }^{54} \mathrm{P}$. oligandrum was isolated on Corn Meal Agar added with Pimaricin, Ampicilliun, Rifampicin and Pentachloronitrobenzene (CMA-PARP) and identified by morphological features. ${ }^{41}$ Polymerase chain reaction (PCR) products were purified with the High Pure PCR Product Purification Kit (Roche Diagnostics, Mannheim, Germany), and sequenced in both directions 
by Macrogen Inc. (Seoul, Republic of Korea). The sequences obtained were then blasted in GenBank.

\subsection{Soil physicochemical properties analysis}

Four soil cores were collected to a depth of $20 \mathrm{~cm}$ from each field and bulked into a single soil sample per field. Samples were mixed well, air-dried for one week and sieved (2-mm to 5-mm mesh size) prior to soil physicochemical analyses. Soil samples were tested for electric conductivity (EC) in water and $\mathrm{pH}$ with a soil solution ratio of 1:5, soil texture by laser diffraction particle size (Diffractometer LS 13 320, Beckman Coulter Inc., Brea, Calif.), soil organic matter (SOM) by dichromate oxidation, ${ }^{55}$ cation exchange capacity (CEC) by the cobaltihexamine method, ${ }^{56}$ carbonate total by infrared (Equilab CO-202; Equilab, Jakarta, Indonesia), assimilable magnesium and calcium by inductively coupled plasma (ICP) spectroscopy (ARL-Fison 3410, USA) and the cobaltihexamine method and P, K, S, Mg, Mn, $\mathrm{Fe}, \mathrm{Ca}$ and Na by ICP and Mehlich method. ${ }^{57}$ Analyses were conducted in the official Regional Laboratory of La Grajera (Logroño, Spain) in April 2017, before the beginning of the experiment.

\subsection{Data analysis}

Prior to statistical analyses, data were checked for normality and homogeneity of variances, and transformed when needed. Percentage data were transformed into arcsin (DI or DS/100) ${ }^{1 / 2}$. Each treatment means (DI, DS, root and shoot weights) was calculated from the corresponding values in each sampling moment. The statistical analysis of the experimental results was carried out in a two-way ANOVA with blocks and treatments as independent variables, and the following dependent variables: DI (\%), DS (\%), root weight (g) and shoot weight (g). In the 3year-old plants, the percentage of reduction (PR) of the fungal pathogen detection at each isolation plant part and for each fungal GTD species was calculated as $\mathrm{PR}=100(\mathrm{PC}-\mathrm{PT}) / \mathrm{PC}$, where $\mathrm{PC}$ is the mean pathogen incidence or severity in the control and PT is the mean pathogen incidence or severity in the BCA treatment. Means were compared by the Student's $t$ least significant difference (LSD) at $P<0.05$. Soil physicochemical variables were subjected to analyses of variance. LSD test was calculated to compare variable means. Data from all experiments were analysed using the Statistix 10 software (Analytical Software).

\section{RESULTS}

\subsection{Plant viability and fungal identification}

None of the treatments had a negative influence on callus or initial shoot growth. The viability of planting material was estimated to be of $94 \%$ and $92 \%$ for the 2 -year-old and 3-year-old plants at the end of growing season, respectively. After HWT, six and four out of the 50 grafted plants stock tested positive for Diplodia seriata and Neofusicoccum parvum, respectively, other fungi associated with GTDs. No black-foot and Petri disease pathogens were isolated from hotwater treated plants. In the 2-year-old plants, a total of 1,650 Petri disease $(83.6 \%$ from the basal end of the rootstock and $16.4 \%$ from roots) and 896 black-foot disease pathogens $(15.8 \%$ from the basal end of the rootstock and $84.2 \%$ from roots) isolates were collected. Petri disease pathogens were identified as C. luteo-olivacea (57.8\%), followed by Pa. chlamydospora (27.3\%) and Pm. minimum (14.9\%).

Black-foot pathogens were identified as Dactylonectria torresensis $(66.4 \%)$, followed by Dactylonectria macrodidyma (22.6\%), Ilyonectria liriodendri (6.2\%) and Dactylonectria alcacerensis $(4.8 \%)$. In the 3-year-old plants, a total of 1,825 Petri disease $(89.4 \%$ from the basal end of the rootstock and $10.6 \%$ from roots) and 1,632 black-foot pathogens $(26.9 \%$ from the basal end of the rootstock and $73.1 \%$ from roots) isolates were collected. Petri disease 
pathogens were identified as C. luteo-olivacea (54.6\%), followed by Pa. chlamydospora (31.1\%) and Pm. minimum (14.3\%). Black-foot pathogens were identified as D. torresensis (66.0\%), followed by I. liriodendri (16.0\%), D. macrodidyma (9.2\%), Ilyonectria robusta (4.4\%), D. alcacerensis (2.5\%) and Ilyonectria pseudodestructans (1.8\%). Representative black-foot and Petri diseases isolate sequences obtained in this study were deposited to GenBank (Supplementary Table S1).

Trichoderma atroviride was isolated from 30 and $22 \%$ of the 2-year-old and 3-year-old plants, respectively. Trichoderma koningii was isolated from 12 and $18 \%$ of the 2-year-old and 3 -year-old plants, respectively. Our attempts to isolate P. oligandrum were unsuccessful.

\subsection{Disease incidence and disease severity in grafted plants}

Neither field site, nor block, nor its interaction significantly affected the DI and DS $(P>0.05$, ANOVA not shown). Therefore, data from both field sites were combined and analysed together. There was a significant effect of treatment on mean Petri disease incidence values in the roots and the basal ends for both 2-year-old and 3-year-old plants (Table 1). In the 3-yearold plants, percentage of infected plants (DI) in the basal ends were significantly lower in treatments with $T$. atroviride SC1 (T3) $(40.2 \% \pm 8.3)$ than in the control treatment $(61.5 \% \pm$ 5.6) (Figure 1A). In both 2-year-old and 3-year-old plants, percentage of infected plants (DI) in the roots were significantly lower in treatments with P. oligandrum Po37 (T5) (2-year-old plants: $7.5 \% \pm 1.4$, and 3-year-old plants: $4.8 \% \pm 1.3$ ) than in the control treatment (2-year-old plants: $23.1 \% \pm 2.8$, and 3-year-old plants: $18.3 \% \pm 3.9$ ) (Figure 1B). Biocontrol treatments had a significant effect on mean Petri disease severity in basal ends of 2-year-old plants, and in roots and basal ends for 3-year-old plants (Table 1). T. atroviride SC1 (T3) in the 2-year-old plants $(19.4 \% \pm 1.4)$ and both Trichoderma spp. treatments (T2: $25.5 \% \pm 2.5$, and T3: $25.8 \% \pm 2.3)$ in the 3-year-old plants significantly reduced the percentage of DS in the basal ends compared to the control treatment (2-year-old plants: $36.1 \% \pm 4.3$, and 3-year-old plants: $39.5 \% \pm 4.9$ ) (Figure 1A). Trichoderma spp. treatments (T2: 9.1\% \pm 1.3 , and T3: $10.8 \% \pm 1.8$ ) resulted in significant lower DS in roots of the 3-year-old plants than the control treatment $(16.8 \% \pm 3.8)$ (Figure 1B).

Analysis of variance showed no significant effect of biocontrol treatments on black-foot disease incidence and severity in roots of both 2-year-old and 3-year-old plants (Table 1). There was a significant effect of treatment on mean black-foot disease incidence values in the basal ends for both 2-year-old and 3-year-old plants (Table 1). In the 2-year-old plants, all treatments resulted in significant lower DI in the basal ends than the control treatment (Figure 2A). In the 3 -year-old plants, percentage of infected plants (DI) in the basal ends were significantly lower in treatments with Streptomyces sp. E1 + R4 (T1) $(4.8 \% \pm 2.1)$ than in the control treatment $(13.2 \% \pm 3.2)$ (Figure 2A). There was a significant effect of treatment on mean black-foot disease severity values in the basal ends of 2-year-old plants (Table 1). Streptomyces sp. E1 + R4 (T1) $(10.0 \% \pm 2.3)$ significantly reduced the percentage of DS in the basal ends compared to the control treatment $(19.1 \pm 0.8)$ (Figure $2 \mathrm{~A})$.

\subsection{Fungal species incidence and severity in grafted plants}

Considering the fungal species within each disease individually, P. oligandrum Po37 (T5) and T. atroviride $\mathrm{SC} 1$ (T3) significantly reduced the DI of C. luteo-olivacea in the roots and the basal ends, respectively, of 2-year-old plants compared to the control treatment $(P<0.05$, ANOVA not shown) (Table 2). Percentage of DI in the roots of both 2-year-old and 3-year-old plants, and DS in the roots of 2-year-old plants caused by Pa. chlamydospora were significantly lower in treatments with $P$. oligandrum Po37 (T5) than in the control treatment $(P<0.05$, ANOVA not shown) (Table 2). In the 3-year-old plants, T. atroviride SC1 (T3) significantly 
reduced both DI and DS caused by Pa. chlamydospora in the basal ends compared to the control treatment $(P<0.05$, ANOVA not shown) (Table 2). Both T. koningii TK7 (T2) and $P$. fluorescens $+B$. atrophaeus (T4) treatments resulted in significant lower DI caused by $P m$. minimum in the roots of 2-year-old plants than the control treatment $(P<0.05$, ANOVA not shown) (Table 2). Furthermore, T. koningii TK7 (T2) treatment resulted in significant lower DS caused by Pm. minimum in the roots of 3 -year-old plants than the control treatment $(P<0.05$, ANOVA not shown) (Table 2). T. atroviride SC1 (T3) significantly reduced the DS of Pm. minimum in the roots of both 2-year-old and 3-year-old plants compared to the control treatment $(P<0.05$, ANOVA not shown) (Table 2).

Regarding black-foot pathogens, all treatments significantly reduced the DI of $D$. torresensis and D. macrodidyma in the basal ends of 2-year-old plants compared to the control treatment $(P<0.05$, ANOVA not shown) (Table 3). Streptomyces sp. E1 + R4 (T1) significantly reduced $D$. torresensis DS in the basal ends of 2-year-old plants and DI in the basal ends of 3year-old plants compared to the control treatment $(P<0.05$, ANOVA not shown) (Table 3$)$. In both the 2-year-old and 3-year-old plants, percentages of DI in the roots and DS in the basal ends caused by $D$. macrodidyma were significantly lower in treatments with Streptomyces sp. $\mathrm{E} 1+\mathrm{R} 4$ (T1) than in the control treatment $(P<0.05$, ANOVA not shown) (Table 3). T. atroviride $\mathrm{SC} 1$ (T3) also resulted in significant lower DS in the basal ends of 3-year-old plants than the control treatment $(P<0.05$, ANOVA not shown) (Table 3). Low levels of Trichoderma spp. $(<30 \%)$ were isolated from roots and basal ends of 2-year-old and 3-year-old plants subjected to T2 and T3 treatments in both fields.

The percentage of reduction (PR) was calculated for treatments statistically different from the control in the 3-years-old plants (Table 4). In roots, P. oligandrum Po37 (T5) provided 93.6\% disease incidence reduction of Pa. chlamydopora. On Trichoderma spp. treated plants, there was a reduction in Pm. minimum severity when compared with untreated controls, which ranged from $80 \%$ for $T$. koningii $\mathrm{TK} 7$ (T2) and $69.6 \%$ for T. atroviride $\mathrm{SC} 1$ (T3). In the basal ends, $T$. atroviride $\mathrm{SC} 1$ (T3) provided $69.4 \%$ disease incidence and $56.6 \%$ disease severity reduction of $P a$. chlamydopora, while $T$. koningii TK7 (T2) provided 52.3\% disease severity reduction of Pm. minimum. None of the BCA treatments statistically reduced the disease incidence and severity of black-foot disease fungi in roots (Tables 3 and 4). In the basal ends, Streptomyces sp. E1 + R4 (T1) reduced the incidence of $D$. torresensis and the severity of $D$. macrodidyma by 89.1 and $100 \%$, respectively. T. atroviride SC1 (T3) provided $100 \%$ disease severity reduction of $D$. macrodidyma.

\subsection{Root and shoot weights in grafted plants, and physicochemical properties of the soil}

Analysis of variance showed no significant effect of biocontrol treatments on the shoot weight of 3-year-old plants ( $P>0.05$, ANOVA not shown) (Figure 3). Mean shoot weight ranged from $55.3 \mathrm{~g} \pm 5.7$ (T3) to $64.9 \mathrm{~g} \pm 8.2$ (T2). Biological control treatments had a significant effect on the root weight of 3-year-old plants $(P<0.05$, ANOVA not shown) (Figure 3). Mean root weight ranged from $41.9 \mathrm{~g} \pm 3.7$ (T3) to $52.9 \mathrm{~g} \pm 2.9$ (C). All treatments resulted in significant lower root weight than the control treatment (Figure 3). Analyses of variance indicated no significant differences for the soil physicochemical properties between fields $(P>0.05$, ANOVA not shown).

\section{DISCUSSION}

This study represents the first approach to evaluate the effectiveness of different antagonistic microorganisms (bacteria, fungi and an oomycete) applied preventively to control black-foot and Petri diseases under field conditions. The use of BCA against soilborne pathogens are on the forefront of research; however, most experiences are on a laboratory scale, thus avoiding 
the problems related to the production of large quantities of antagonists and their formulations, and disease control trials are performed in simplified environment such as growth chambers or experimental greenhouses, thus avoiding the risk of large-scale experiments in the field.

In this study, Petri disease infection was mainly detected in the basal ends of the rootstock, while fungi associated with black-foot disease were most frequently isolated from roots. $D$. torresensis was the most frequent isolated species $(>60 \%)$ associated with black-foot disease at both plant ages. This agrees with previous research carried out on black-foot in Europe. ${ }^{9-11}$ Regarding Petri disease, more than $80 \%$ of the fungi were identified as C. luteo-olivacea and $\mathrm{Pa}$. chlamydospora at both plant ages. Both fungal species were frequently isolated from nursery stock and young vines worldwide. ${ }^{3}$

In our specific pathosystems, the effectiveness of some BCA in reducing the incidence and severity of both diseases under field conditions were dependent on the plant part analysed and the plant age. Streptomyces sp. E1 + R4 treatment was highly effective in reducing black-foot disease incidence at both plants ages and the severity of 2-year-old plants in the basal ends. However, the effect of these actinobacteria against Petri disease pathogens after 2 years in the field was very low. In contrast, Álvarez-Pérez et al. ${ }^{38}$ evaluated the effectiveness of these bacterial strains individually, previously isolated from the endo- (strain E1) and rhizosphere (strain R4) of the grapevine root system, for black-foot and Petri diseases control in 1-year-old grafted plants under field conditions by partially immersing the grafts (up to $10 \mathrm{~cm}$ depth) in a rooting hormone solution containing the actinobacteria for $24 \mathrm{~h}$ at room temperature. They found significant reductions of the infection rates at the lower end of the rootstock of the fungal pathogens Dactylonectria sp., Ilyonectria sp., Pm. minimum and Pa. chlamydospora. ${ }^{38}$ These differences in the effectiveness of the bacteria against Petri disease between experiments could be due to the commonly unpredictably behaviour of BCA when tested in different environments. ${ }^{58}$

Other bacterial treatment tested in our study was a commercial product containing Pseudomonas fluorescens and Bacillus atrophaeus. No biocontrol effect of this treatments was observed on fungal pathogens associated with black-foot and Petri diseases. Despite this fact, some strains of these bacterial species have been previously reported as plant growth-promoting bacteria (PGPB) and have been found to be potential BCA of plant diseases in several crops. ${ }^{59-}$ ${ }^{62}$ In grapevine, different $P$. fluorescens strains were identified as prospective new BCA against Botrytis cinerea ${ }^{63}$ and to induce systemic resistance against Plasmopara viticola and B. cinerea by priming common and distinct defensive pathways. ${ }^{64}$

The in vitro effects of beneficial bacteria in reducing GTDs has been also tested. ${ }^{65,66}$ Bacillus subtilis AG1 showed promising in reducing the growth of Lasiodiplodia theobromae, Pa. chlamydospora, and Pm. minimum in an artificial culture medium. ${ }^{34}$ Rezgui et al. ${ }^{37}$ recently identified antagonistic traits against GTDs pathogens of several $B$. subtilis strains inhabiting the wood tissues of mature grapevines in Tunisia. The antagonistic activity of Pantoea agglomerans and Bacillus pumilus against $N$. parvum and Pa. chlamydospora was demonstrated in inoculated ungrafted grapevine cuttings. ${ }^{35,36}$ A recent study performed by Trotel-Aziz et al. ${ }^{40}$ highlighted the effect of B. subtilis strain PTA-271 to efficiently attenuate the characteristic Botryosphaeria dieback symptoms caused by N. parvum.

Most studies on biological control of GTDs have examined the application of Trichoderma spp. in grapevine nurseries and young vineyards. ${ }^{21-25,29}$ In our study, we individually evaluated two Trichoderma-based products containing T. koningii strain TK7 and T. atroviride strain $\mathrm{SC} 1$. A certain effect was observed in reducing Pm. minimum disease incidence for 2-year-old plants and disease severity for 3-year-old plants at the root level by T. koningii TK7 treatment. Little information is still available related to the biocontrol effect of TK7 strain to combat plants' fungal pathogens. Howell et al. ${ }^{67}$ showed that the application of T. koningii TK7 to cotton seeds before planting was ineffective to control cotton seedlings damping-off in 
artificially Rhizoctonia solani-infested cotton field soil flats. Other strains of this species have been recently reported as potential BCA for fungal pathogens in different crops, such as Fusarium oxysporum f. sp. melonis in melon ${ }^{68}$ or Sclerotium rolfsii in groundnut. ${ }^{69}$

Trichoderma atroviride $\mathrm{SC1}$ was effective in reducing $\mathrm{Pa}$. chlamydospora disease incidence and severity in the basal ends of 3-year-old plants. In accordance with our results, a study carried out in Spain by Berbegal et al. ${ }^{33}$ also found reductions in the incidence and severity of Pa. chlamydospora and Pm. minimum when analysed the rootstock basal end and root system of 1-day $T$. atroviride $\mathrm{SC} 1$ inoculated grafted plants in nurseries. In the same study, Berbegal et al..$^{33}$ also evaluated the effect of $T$. atroviride SC1 treatment in two fields during two growing seasons. The basal parts of the treated plants were soaked for $1 \mathrm{~h}$ in a $T$. atroviride $\mathrm{SC} 1$ suspension before planting, observing no BCA effect on incidence and severity of blackfoot disease associated pathogens and significant reductions on pathogens associated with Petri disease at both fields after the first growing season. In Italian grapevine nurseries, the application of $T$. atroviride strain $\mathrm{SC} 1$ at several stages of the nursery process (pre-storage and pre-grafting hydration, stratification, callusing, and rooting) protected plants from infection by Pm. minimum and $\mathrm{Pa}$. chlamydospora after a single artificial inoculation with both pathogens following the grafting stage. ${ }^{28}$

Regarding P. oligandrum Po37 treatment, a significant reduction of Petri disease incidence and severity was observed in 2-year-old plants and disease incidence in 3-year-old plants, at roots level. Yacoub et al. ${ }^{41}$ reported a significant reduction in necrosis length caused by $\mathrm{Pa}$. chlamydospora when the roots of 'Cabernet Sauvignon' cuttings were colonized by different $P$. oligandrum strains. The efficacy of $P$. oligandrum strain $\mathrm{Sto} 7$ in reducing the necrosis length caused by $N$. parvum and Pa. chlamydospora was demonstrated on grafted young 'Cabernet Sauvignon' vines cultivated in a nursery greenhouse, separately or in combination with two bacterial strains previously isolated from vineyards. ${ }^{42}$ The ability of $P$. oligandrum strain Po37 to act as an inducer of plant systemic resistance against pathogens is thought to be due to the presence of three elicitin-like proteins in its genome. ${ }^{70}$

Diverse formulations (dry or water suspensions), application methods and times of exposure of plants to BCA have been tested in the different studies carried out to assess the biocontrol potential of antagonist microorganisms. ${ }^{28,30,33,38,41,42,71-73}$ In our assay, a 24-h soaking of the trimmed root systems and the basal end of the plants in BCA water suspensions was carried out before planting, but the percentage of Trichoderma spp. recovery was low in all cases $(<30 \%)$. In this sense, Halleen et al. ${ }^{74}$ were also able to only isolate a $2.3 \%$ of Trichoderma spp. from the basal ends of the rootstock and none from roots of grafted plants subjected to Trichoderma treatments, applied by dipping the basal ends of the rootstock for 1 min before planting, after 7 months in a nursery field. In a recent study, González-García et $a l .{ }^{72}$ evaluated the colonization efficiency of Streptomyces sp. in the root system by comparing two inoculation methods, plant immersion in a bacterial suspension or direct injection of the bacterial suspension into the vegetal tissues and concluded that both methods allowed effective BCA colonization. This is also in accordance with Berbegal et al. ${ }^{33}$ who used 24-h soak in $T$. atroviride $\mathrm{SC} 1$ water suspension to inoculate 110R rootstock cuttings before grafting, with percentages of recovery over $80 \%$ at both nursery and vineyard experiments. Van Jaarsveld et $a l .{ }^{73}$ evaluated different methods of application of $T$. atroviride on commercially planted nursery vines and concluded that dipping of basal ends in the Trichoderma dry formulation consistently gave higher colonization percentages than the 1-h soak of bases of vines before planting or Trichoderma field drenching. Further research is needed to evaluate the effectiveness of soaking vines in T. koningii TK7 or T. atroviride SC1 dry formulations compared to soaking vines for 24-h in BCA water suspensions before planting.

Biological control agent treatments did not affect the shoot weight, and root weight was significantly lower for all BCA treatments with respect to the untreated control at the end of the 
second growing season (3-year-old plants). The impact of BCA treatments on grapevine development was very variable on previous research. ${ }^{29,73,74}$ Trichoderma spp. and B. subtilisbased treatments resulted in lower mean root and shoot dry weight values when compared with the negative controls. ${ }^{29}$ Nevertheless, Halleen et al. ${ }^{74}$ found that none of the Trichoderma formulations tested yielded plants with roots or shoots mass significantly different than the water treated controls. Berbegal et al. ${ }^{33}$ observed a significantly higher undried shoot weight for T. atroviride SC1 treated plants at the end of the first growing season, but this effect was not observed in the second growing season. Likewise, the application of actinobacteria to grafted grapevine plants did not show a significant effect, either positive or negative, on plants growth. ${ }^{38}$ In contrast, Fourie et al. ${ }^{22}$ observed that $T$. harzianum treatments significantly improved root development but not shoot mass in comparison with the control vines in nurseries. Several studies indicate that BCA treatments can enhance the growth of other crops, such as tomato ${ }^{75}$ or rice. ${ }^{76}$ All this variability could be related to the lack of proper long-standing implantation by these antagonist microorganisms in grapevine roots or the vigour level of the rootstock cultivar tested. BCA are living organisms whose activities depend mainly on the different physicochemical environmental conditions to which they are subjected, ${ }^{77}$ and the greatest long-term effects probably occur with rhizosphere-competent strains with the ability to colonize and grow in association with plant roots. ${ }^{78}$

\section{CONCLUSIONS}

This study highlighted the potential of some BCA to reduce GTD infection under field conditions. No single BCA application was able to control both diseases. Further studies should evaluate the combination of the disease-suppressive activity of two or more beneficial microbiomes in a biocontrol preparation against black-foot and Petri diseases. Our results also open up the possibility to combine the application of BCA as a pre- planting strategy with other measures in an Integrated Pest Management (IPM) programme against GTDs. For example, BCA can be applied after hot-water treatment (HWT) of dormant grafted plants or after soil biofumigation. In this regard, recent research highlighted the effectiveness of $\mathrm{HWT}$ at $53^{\circ} \mathrm{C}$ for $30 \mathrm{~min}^{45}$ and white mustard biofumigation ${ }^{30}$ to reduce GTD incidence in planting material and grapevine nursery soil, respectively.

\section{ACKNOWLEDGEMENTS}

We thank researchers of the "Instituto de Investigación de la Viña y el Vino" in the "Universidad de León" for providing the Streptomyces sp. strains. M.P. Martínez-Diz was supported by the FPI-INIA program from the INIA. D. Gramaje was supported by the Ramón y Cajal program, Spanish Government (RYC-2017-23098).

\section{REFERENCES}

1 Gramaje D, Urbez-Torres JR and Sosnowski MR, Managing grapevine trunk diseases with respect to etiology and epidemiology: current strategies and future prospects. Plant Dis 102:12-39 (2018).

2 Halleen F, Fourie, PH and Crous PW, A review of black foot disease of grapevine. Phytopathol Mediterr 45:S55-67 (2006).

3 Gramaje D and Armengol J, Fungal trunk pathogens in the grapevine propagation process: potential inoculum sources, detection, identification, and management strategies. Plant Dis 95:1040-1055 (2011).

4 Agustí-Brisach C and Armengol J, Black-foot disease of grapevine: an update on taxonomy, epidemiology and management strategies. Phytopathol Mediterr 52:245-261 (2013). 
5 Martínez-Diz MP, Díaz-Losada E, Barajas E, Ruano-Rosa D, Andrés-Sodupe and Gramaje D, Screening of Spanish Vitis vinifera germplasm for resistance to Phaeomoniella chlamydospora. Scient Hortic 246:104-109 (2019a).

6 Aigoun-Mouhous W, Elena G, Cabral A, León M, Sabaou N, Armengol J, Chaouia C, Mahamedi $\mathrm{AE}$ and Berraf-Tebbal A, Characterization and pathogenicity of Cylindrocarpon-like asexual morphs associated with black foot disease in Algerian grapevine nurseries, with the description of Pleiocarpon algeriense sp. nov. Eur J Plant Pathol 154:887-901 (2019).

7 Lawrence DP, Nouri MT and Trouillas FP, Taxonomy and multi-locus phylogeny of cylindrocarpon-like species associated with diseased roots of grapevine and other fruit and nut crops in California. FUSE 4:59-75 (2019).

8 Berlanas C, Ojeda S, López-Manzanares B, Andrés-Sodupe B, Bujanda R, Martínez-Diz MP, Díaz-Losada E and Gramaje D, Occurrence and diversity of black-foot disease fungi in symptomless grapevine nursery stock in Spain. Plant Dis 104:94-104 (2020).

9 Reis P, Cabral A, Nascimento T, Oliveira H and Rego C, Diversity of Ilyonectria species in a young vineyard affected by black foot disease. Phytopathol Mediterr 52:335-346 (2013).

10 Berlanas C, López-Manzanares B and Gramaje D, Estimation of viable propagules of blackfoot disease pathogens in grapevine cultivated soils and their relation to production systems and soil properties. Plant Soil 417:467-479 (2017).

11 Carlucci A, Lops F, Mostert L, Halleen F and Raimondo, ML, Occurrence fungi causing black foot on young grapevines and nursery rootstock plants in Italy. Phytopathol Mediterr 56:10-39 (2017).

12 Petit E, Barriault E, Baumgartner E, Wilcox WF and Rolshausen PE, Cylindrocarpon species associated with black-foot of grapevine in northeastern United States and southeastern Canada. Am J Enol Viticult 62:177-183 (2011).

13 Mostert L, Groenewald JZ, Summerbell RC, Gams W and Crous PW, Taxonomy and pathology of Togninia (Diaporthales) and its Phaeoacremonium anamorphs. Stud Mycol 54:1-113 (2006).

14 Gramaje D, Mostert L and Armengol J, Characterization of Cadophora luteo-olivacea and C. melinii isolates obtained from grapevines and environmental samples from grapevine nurseries in Spain. Phytopathol Mediterr 50:S112-S126 (2011).

15 Gubler WD, Rooney-Latham S, Vasquez SJ and Eskalen A, Esca (Black Measles) and Petri disease, in Grape Pest Management, Third Edition, ed. by Bettiga LJ, University of California, Agriculture and Natural Resources, Oakland, CA, Publication 3343. pp. 120126 (2013).

16 Gramaje D, Mostert L, Groenewald JZ and Crous PW, Phaeoacremonium: from esca disease to phaeohyphomycosis. Fungal Biol 119:759-783 (2015).

17 Martínez-Diz MP, Andrés-Sodupe M, Bujanda R, Díaz-Losada E, Eichmeier A and Gramaje D, Soil-plant compartments affect fungal microbiome diversity and composition in grapevine. Fungal Ecol 41:234-244 (2019b).

18 Mondello V, Songy A, Battiston E, Pinto C, Coppin C, Trotel-Aziz P and Fontaine F, Grapevine trunk diseases: a review of fifteen years of trials for their control with chemicals and biocontrol agents. Plant Dis 7:1189-1217 (2018).

19 Larignon P, Darné G, Ménard E, Desaché F and Dubos B, Comment agissait l'arsénite de sodium sur l'esca de la vigne? Prog Agric Vitic 125:642-651 (2008).

20 Spinosi J, Févotte J and Vial G, Éléments techniques sur l'exposition professionnelle aux pesticides arsenicaux. Matrice cultures - expositions aux pesticides arsenicaux. Institut de veille sanitaire, Saint-Maurice, France (2009).

21 Halleen F and Fourie P, 2016. An integrated strategy for the proactive management of grapevine trunk disease pathogen infections in grapevine nurseries. S Afr J Enol and Vitic 
37:104-114.

22 Fourie PH, Halleen F, van der Vyver J and Schrueder W, Effect of Trichoderma treatments on the occurrence of decline pathogens on the roots and rootstocks of nursery plants. Phytopathol Mediterr 40S, 473-478 (2001).

23 Di Marco S, Osti F and Cesari A, Experiments on the control of Esca by Trichoderma. Phytopathol Mediterr 43:108-115 (2004).

24 Fourie PH and Halleen F, Proactive control of Petri disease of grapevine through treatment of propagation material. Plant Dis 88:1241-1245 (2004).

25 Fourie PH and Halleen F, Chemical and biological protection of grapevine propagation material from trunk disease pathogens. Eur J Plant Path 116:255-265 (2006).

26 Petit E and Gubler WD, Influence of Glomus intraradices on black foot disease caused by Cylindrocarpon macrodidymum on Vitis rupestris under controlled conditions. Plant Dis 90:1481-1484 (2006).

27 Mutawila C, Fourie PH, Halleen F and Mostert L, Grapevine cultivar variation to pruning wound protection by Trichoderma species against trunk pathogens. Phytopathol Mediterr 50:S264-S276 (2011).

28 Pertot I, Prodorutti D, Colombini A and Pasini L, Trichoderma atroviride SC1 prevents Phaeomoniella chlamydospora and Phaeoacremonium aleophilum infection of grapevine plants during the grafting process in nurseries. Biocontrol 61:257-267 (2016).

29 Santos RF, Heckler LI, Lazarotto M, Garrido LR, Rego C and Blume E, Trichoderma spp. and Bacillus subtilis for control of Dactylonectria macrodidyma in grapevine. Phytopathol Mediterr 55:293-300 (2016).

30 Berlanas C, Andrés-Sodupe M, López-Manzanares B, Maldonado-González MM and Gramaje D, Effect of white mustard cover crop residue, soil chemical fumigation and Trichoderma spp. root treatment on black-foot disease control in grapevine. Pest Manag Sci 74:2864-2873 (2018).

31 Del Frari G, Cabral A, Nascimento T, Boavida Ferreira R and Oliveira H, Epicoccum layuense a potential biological control agent of esca-associated fungi in grapevine. PLoS ONE 14:e0213273 (2019).

32 Mondello V, Spagnolo A, Larignon P, Clément C and Fontaine F, Phytoprotection potential of Fusarium proliferatum for control of Botryosphaeria dieback pathogens in grapevine. Phytopathol Mediterr 58:293-306 (2019).

33 Berbegal M, Ramón-Albalat A, León M and Armengol J, Evaluation of long-term protection from nursery to vineyard provided by Trichoderma atroviride SC1 against fungal grapevine trunk pathogens. Pest Manag Sci 76:967-977 (2020).

34 Alfonzo A, Conigliaro G, Torta L, Burruano S and Moschetti G, Antagonism of Bacillus subtilis strain AG1 against vine wood fungal pathogens. Phytopathol Mediterr 48: 155-158 (2009).

35 Haidar R, Deschamps A, Roudet J, Calvo-Garrido C, Bruez E, Rey and Fermaud M, Multiorgan screening of efficient bacterial control agents against two major pathogens of grapevine. Biol Control 92:55-65 (2016a).

36 Haidar R, Roudet J, Bonnard O, Dufour M, Corio-Costet M, Fert M, Gautier T, Deschamps A and Fermaud M, Screening and modes of action of antagonistic bacteria to control the fungal pathogen Phaeomoniella chlamydospora involved in grapevine trunk diseases. Microbiol Res 192:172-184 (2016b).

37 Rezgui A, Ben Ghnaya-Chakroun A, Vallance J, Bruez E, Hajlaoui MR, Sadfi-Zouaoui N and Rey P, Endophytic bacteria with antagonistic traits inhabit the wood tissues of grapevines from Tunisian vineyards. Biol Control 99:28-37 (2016).

38 Álvarez-Pérez JM, González-García S, Cobos R, Olego MA, Ibañez A, Díez-Galán A, Garzón-Jimeno E and Coque JJR, Use of endophytic and rhizospheric actinobacteria from 
grapevine plants to reduce nursery fungal infections that lead to young grapevine decline. Appl Environ Microb 83: e01564-17 (2017).

39 Andreolli M, Zapparoli G, Angelini E, Lucchetta G, Silvia Lampis S and Vallini G, Pseudomonas protegens MP12: A plant growth-promoting endophytic bacterium with broad-spectrum antifungal activity against grapevine phytopathogens. Microbiol Res 219:123-131 (2019).

40 Trotel-Aziz P, Abou-Mansour E, Courteaux B, Rabenoelina F, Clément C, Fontaine F and Aziz A, Bacillus subtilis PTA-271 Counteracts Botryosphaeria Dieback in Grapevine, Triggering Immune Responses and Detoxification of Fungal Phytotoxins. Front Plant Sci 10:25 (2019).

41 Yacoub A, Gerbore J, Magnin N, Chambon P, Dufour MC, Corio-Costet MF, Guyoneaud R and Rey P, Ability of Pythium oligandrum strains to protect Vitis vinifera L., by inducing plant resistance against Phaeomoniella chlamydospora, a pathogen involved in Esca, a grapevine trunk disease. Biol Control 92:7-16 (2016).

42 Daraignes L, Gerbore J, Yacoub A, Dubois L, Romand C, Zekri O, Roudet J, Chambon P and Fermaud M, Efficacy of $P$. oligandrum affected by its association with bacterial BCAs and rootstock effect in controlling grapevine trunk diseases. Biol Control 119:59-67 (2018).

43 MAPA, Official Registry of Phytosanitary Products, Ministerio de Agricultura, Pesca y Alimentación, Consulted on 13 January 2020 from https://www.mapa.gob.es/es/agricultura/temas/sanidad-vegetal/productosfitosanitarios/registro/menu.asp, Spain (2020).

44 Gramaje D, Alaniz S, Abad-Campos P, García-Jiménez J and Armengol J, Effect of hotwater treatments in vitro on conidial germination and mycelial growth of grapevine trunk pathogens. Ann Appl Biol 156:231-241 (2010).

45 Eichmeier A, Pecenka J, Penázová E, Baránek M, Català-García S, León M, Armengol J and Gramaje D, High-throughput amplicon sequencing-based analysis of active fungal communities inhabiting grapevine after hot-water treatments reveals unexpectedly high fungal diversity. Fungal Ecol 36:26-38 (2018).

46 Dhingra O and Sinclair JB, Basic Plant Pathology Methods, CRC Press, Boca Raton, FL, p. 434 (1995).

47 Crous PW, Groenewald JZ, Risede JM and Hywel-Jones NL, Calonectria species and their Cylindrocladium anamorphs: Species with sphaeropedunculate vesicles. Stud Mycol 50:415-429 (2004).

48 Cabral A, Groenewald JZ, Rego C, Oliveira H and Crous PW, Cylindrocarpon root rot: Multi-gene analysis reveals novel species within the Ilyonectria radicicola species complex. Mycol Progr 11:655-688 (2012a).

49 Cabral A, Rego C, Nascimento T, Oliveira H, Groenewald JZ and Crous PW, Multi-gene analysis and morphology reveal a novel Ilyonectria species associated with black foot disease of grapevines. Fungal Biol 116:62-80 (2012b).

50 Tegli S, Bertelli E and Surico G, Sequence analysis of ITS ribosomal DNA in five Phaeoacremonium species and development of a PCR-based assay for the detection of $P$. chlamydosporum and P. aleophilum in grapevine tissue. Phytopathol Mediterr 39:134-149 (2000).

51 O'Donnell $\mathrm{K}$ and Cigelnik E, Two divergent intragenomic rDNA ITS2 types within a monophyletic lineage of the fungus Fusarium are nonorthologus. Mol Phylogenet Evol 7:103-116 (1997).

52 Glass NL and Donaldson G, Development of primer sets designed for use with PCR to amplify conserved genes from filamentous ascomycetes. Appl Environ Microbiol 61: 1323-1330 (1995). 
53 Travadon R, Lawrence DP, Rooney-Latham S, Gubler WD, Wilcox WF, Rolshausen PE and Baumgartner K, Cadophora species associated with wood-decay of grapevine in North America. Fungal Biol 119:53-66 (2015).

54 Gardes M and Bruns TD, ITS primers with enhanced specificity for Basidiomycetes: application to the identification of mycorrhizae and rusts. Mol Ecol 2:113-118 (1993).

55 Nelson DW and Sommers LE, Total carbon, organic carbon, and organic matter, in Methods of Soil Analysis Part 2, Second Edition, ed. by Page AL, American Society of Agronomy, Soil Science Society of America, Madison, WI, pp. 539-594 (1982).

56 Orsini L and Remy JC, Utilisation du chlorure de cobaltihexammine pour la determina-tion simultanée de la capacité d'échange et des bases échangeables des sols. Scie Sol 4:269275 (1976).

57 Mehlich A, Mehlich 3 soil test extractant: a modification of Mehlich 2 extractant. Commun Soil Sci Plant Anal 15:1409-1416 (1984).

58 Vannacci $\mathrm{G}$ and Gullino ML, Use of biocontrol agents against soil-borne pathogens: results and limitations. Acta Hortic 532:79-88 (2000).

59 Compant S, Duffy B, Nowak J, Clément C and Barka EA, Use of plant growth-promoting bacteria for biocontrol of plant diseases: principles, mechanisms of action, and future prospects. Appl Environ Microbiol 71:4951-4959 (2005).

60 Zhang X, Li B, Wang Y, Guo Q, Lu X, Li S and Ma P, Lipopeptides, a novel protein, and volatile compounds contribute to the antifungal activity of the biocontrol agent Bacillus atrophaeus CAB-1. Appl Microbiol Biotechnol 97:9525-9534 (2013).

61 Guardado-Valdivia L, Tovar-Pérez E, Chacón-López A, López-García U, GutiérrezMartínez P, Stoll A and Aguilera S, Identification and characterization of a new Bacillus atrophaeus strain B5 as biocontrol agent of postharvest anthracnose disease in soursop (Annona muricata) and avocado (Persea americana). Microbiol Res 210:26-32 (2018).

62 Ma J, Wang C, Wang H, Liu K, Zhang T, Yao L, Zhao Z, Du B and Ding Y, Analysis of the Complete Genome Sequence of Bacillus atrophaeus GQJK17 Reveals Its Biocontrol Characteristics as a Plant Growth-Promoting Rhizobacterium. Biomed Res Int 2018:9473542 (2018).

63 Trotel-Aziz P, Couderchet M, Biagianti S and Aziz A, Characterization of new bacterial biocontrol agents Acinetobacter, Bacillus, Pantoea and Pseudomonas spp. mediating grapevine resistance against Botrytis cinerea. Environ Exp Bot 64:21-32 (2008).

64 Lakkis S, Trotel-Aziz P, Rabenoelina F, Schwarzenberg A, Nguema-Ona E, Clément C and Aziz A, Strengthening Grapevine Resistance by Pseudomonas fluorescens PTA-CT2 Relies on Distinct Defense Pathways in Susceptible and Partially Resistant Genotypes to Downy Mildew and Gray Mold Diseases. Front Plant Sci 10:1112 (2019).

65 Compant S, Brader G, Muzammil S, Sessitsch A, Lebrihi A and Mathieu F, Use of beneficial bacteria and their secondary metabolites to control grapevine pathogen diseases. BioControl 58:435-455 (2013).

66 Compant S and Mathieu F, Biocontrol of major grapevine diseases: leading research, CABI, Wallingford, UK, pp. 160-170 (2017).

67 Howell CR, Hanson LE, Stipanovic RD and Puckhaber LS, Induction of Terpenoid Synthesis in Cotton Roots and Control of Rhizoctonia solani by Seed Treatment with Trichoderma virens. Phytopathology 90:248-252 (2000).

68 Gava CAT and Pinto JM, Biocontrol of melon wilt caused by Fusarium oxysporum Schlect f. sp. melonis using seed treatment with Trichoderma spp. and liquid compost. Biol Control 97:13-20 (2016).

69 Hirpara DG, Gajera HP, Hirapara JG and Golakiya BA, Inhibition coefficient and molecular diversity of multi stress tolerant Trichoderma as potential biocontrol agent against Sclerotium rolfsii Sacc. Infect Genet Evol 55:75-92 (2017). 
70 Berger H, Yacoub A, Gerbore J, Grizard D, Rey P, Sessitsch A and Compant S, Draft Genome Sequence of Biocontrol Agent Pythium oligandrum Strain Po37, an Oomycota. Genome Announc 4:e0215-16 (2016).

71 Yacoub A, Gerbore J, Magnin N, Haidar R, Compant S and Rey P, Transcriptional analysis of the interaction between the oomycete biocontrol agent, Pythium oligandrum, and the roots of Vitis vinifera L. Biol Control 120:26-35 (2018).

72 González-García S, Álvarez-Pérez JM, Sáenz de Miera LE, Cobos R, Ibáñez A, Díez-Galán A, Garzón-Jimeno E and Coque JJR, Developing tools for evaluating inoculation methods of biocontrol Streptomyces sp. strains into grapevine plants. PLoS ONE 14:e0211225 (2019).

73 Van Jaarsveld W, Stempien E, Pierron R, Hallen F and Mostert L, An overview of lessons learnt in the application of Trichoderma products in grapevine nurseries. Phytopathol Mediterr 58:423. (2019).

74 Halleen F, Fourie PH and Crous PW, Control of black foot disease in grapevine nurseries. Plant Pathol 56:637-645 (2007).

75 Kaur T, Rani R and Manhas RK, Biocontrol and plant growth promoting potential of phylogenetically new Streptomyces sp. MR14 of rhizospheric origin. AMB Express 9:125 (2019).

76 Suárez-Moreno ZR, Vinchira-Villarraga DM, Vergara-Morales DI, Castellanos L, Ramos FA, Guarnaccia C, Degrassi G, Venturi V and Moreno-Sarmiento N, Plant-Growth Promotion and Biocontrol Properties of Three Streptomyces spp. Isolates to Control Bacterial Rice Pathogens. Front Microbiol 10:290 (2019).

77 Benitez T, Rincon AM, Limon MC and Codon AC, Biocontrol mechanisms of Trichoderma strains. Int Microbiol 7:249-260 (2004).

78 Harman GE, Howell CR, Viterbo A, Chet I and Lorito M, Trichoderma speciesopportunistic, a virulent plant symbionts. Nat Rev 2:43-56 (2004). 
Table 1. Effects of variables on disease incidence (DI) and disease severity (DS) in roots and basal ends of rootstock of grapevine grafted plants.

\begin{tabular}{|c|c|c|c|c|c|c|c|c|c|c|}
\hline \multirow{3}{*}{$\begin{array}{l}\text { Petri disease } \\
\text { Variables }\end{array}$} & \multicolumn{5}{|c|}{ 2-year-old plants } & \multicolumn{5}{|c|}{ 3-year-old plants } \\
\hline & \multirow[b]{2}{*}{$d f^{a}$} & \multicolumn{2}{|c|}{ DI (\%) } & \multicolumn{2}{|c|}{ DS (\%) } & \multicolumn{3}{|c|}{ DI $(\%)$} & \multicolumn{2}{|c|}{ DS (\%) } \\
\hline & & $\mathrm{MS}^{\mathrm{b}}$ & $P$ value $^{\mathrm{c}}$ & MS & $P$ value & $\mathrm{df}$ & MS & $P$ value & $\mathrm{MS}$ & $P$ value \\
\hline \multicolumn{11}{|l|}{ Roots } \\
\hline Block & 3 & 0.0034 & 0.9920 & 0.0129 & 0.8115 & 3 & 0.0036 & 0.5770 & 0.0332 & 0.9112 \\
\hline Treatment & 5 & 0.0162 & 0.0003 & 0.0196 & 0.2107 & 5 & 0.0202 & 0.0010 & 0.0708 & 0.0418 \\
\hline Error & 63 & 0.0029 & & 0.0133 & & 63 & 0.0042 & & 2.1901 & \\
\hline \multicolumn{11}{|l|}{ Basal ends } \\
\hline Block & 3 & 0.03102 & 0.7304 & 0.01033 & 0.9031 & 3 & 0.03008 & 0.4951 & 0.02974 & 0.9954 \\
\hline Treatment & 5 & 0.03810 & 0.0411 & 0.00806 & 0.0397 & 5 & 0.03400 & 0.0433 & 0.01761 & 0.0462 \\
\hline Error & 63 & 0.01686 & & 0.01890 & & 63 & 0.01770 & & 0.02023 & \\
\hline \multirow[t]{2}{*}{ Black-foot disease } & \multicolumn{5}{|c|}{ 2-year-old plants } & \multicolumn{5}{|c|}{ 3-year-old plants } \\
\hline & \multicolumn{3}{|c|}{ DI (\%) } & \multicolumn{2}{|c|}{ DS (\%) } & \multicolumn{2}{|r|}{ DI $(\%)$} & \multicolumn{3}{|c|}{ DS (\%) } \\
\hline Variables & $\mathrm{df}$ & MS & $P$ value & MS & $P$ value & $\mathrm{df}$ & MS & $P$ value & $\mathrm{MS}$ & $P$ value \\
\hline \multicolumn{11}{|l|}{ Roots } \\
\hline Block & 3 & 0.0141 & 0.9945 & 0.0071 & 0.9110 & 3 & 0.1212 & 0.9932 & 0.0448 & 0.8234 \\
\hline Treatment & 5 & 0.0024 & 0.9973 & 0.0121 & 0.7817 & 5 & 0.0082 & 0.9162 & 0.0044 & 0.0526 \\
\hline Error & 63 & 0.0393 & & 0.0247 & & 63 & 0.0282 & & 0.0467 & \\
\hline \multicolumn{11}{|l|}{ Basal ends } \\
\hline Block & 3 & 0.0076 & 0.8712 & 0.0081 & 0.7883 & 3 & 0.0135 & 0.9003 & 0.0328 & 0.9991 \\
\hline Treatment & 5 & 0.0282 & 0.0413 & 0.0328 & 0.0417 & 5 & 0.0167 & 0.0389 & 0.0151 & 0.9404 \\
\hline Error & 63 & 0.0136 & & 0.0501 & & 63 & 0.0233 & & 0.0613 & \\
\hline
\end{tabular}

${ }^{\mathrm{a}} \mathrm{df}=$ degrees of freedom.

${ }^{\mathrm{b}} \mathrm{MS}=$ mean square.

c Significance level $P<0.05$. 
Table 2. Mean disease incidence (DI) and severity (DS) of Petri disease pathogens isolated from the roots and basal ends of the rootstock of 2-year-old and 3-year-old grafted plants subjected to various treatments prior to planting in two fields in Logroño (La Rioja).

\begin{tabular}{|c|c|c|c|c|c|c|c|c|}
\hline \multicolumn{9}{|l|}{ Cadophora luteo-olivacea } \\
\hline & \multicolumn{4}{|c|}{ 2-year-old plants } & \multicolumn{4}{|c|}{ 3-year-old plants } \\
\hline & \multicolumn{2}{|c|}{ DI $(\%)^{\mathrm{a}}$} & \multicolumn{2}{|c|}{ DS $(\%)^{\mathrm{a}}$} & \multicolumn{2}{|c|}{ DI $(\%)$} & \multicolumn{2}{|c|}{ DS (\%) } \\
\hline & Roots & Basal ends & Roots & Basal ends & Roots & Basal ends & Roots & Basal ends \\
\hline T1. Streptomyces sp. E1 + R4 & $8.1 \mathrm{a}$ & $24.4 \mathrm{ab}$ & $20.4 \mathrm{a}$ & $26.7 \mathrm{a}$ & $6.9 \mathrm{a}$ & $25.6 \mathrm{a}$ & $19.4 \mathrm{a}$ & $31.3 \mathrm{a}$ \\
\hline T2. Trichoderma koningii TK7 & $5.6 \mathrm{ab}$ & $34.4 \mathrm{a}$ & $20.4 \mathrm{a}$ & $24.5 \mathrm{a}$ & $5.6 \mathrm{a}$ & $34.4 \mathrm{a}$ & $19.6 \mathrm{a}$ & $28.4 \mathrm{a}$ \\
\hline T3. Trichoderma atroviride $\mathrm{SC} 1$ & $6.9 \mathrm{ab}$ & $20.6 \mathrm{~b}$ & $21.0 \mathrm{a}$ & $30.3 \mathrm{a}$ & $5.0 \mathrm{a}$ & $28.1 \mathrm{a}$ & $19.2 \mathrm{a}$ & $27.6 \mathrm{a}$ \\
\hline T4. Pseudomonas fluorescens + Bacillus atrophaeus & $6.3 \mathrm{ab}$ & $31.3 \mathrm{ab}$ & $22.3 \mathrm{a}$ & $30.7 \mathrm{a}$ & $6.3 \mathrm{a}$ & $31.3 \mathrm{a}$ & $20.4 \mathrm{a}$ & $35.0 \mathrm{a}$ \\
\hline T5. Pythium oligandrum Po37 & $3.8 \mathrm{~b}$ & $31.9 \mathrm{ab}$ & $21.3 \mathrm{a}$ & $30.3 \mathrm{a}$ & $5.0 \mathrm{a}$ & $31.9 \mathrm{a}$ & $17.5 \mathrm{a}$ & $31.0 \mathrm{a}$ \\
\hline Control $(\mathrm{C})$ & $7.5 \mathrm{a}$ & $38.1 \mathrm{a}$ & $25.2 \mathrm{a}$ & $33.8 \mathrm{a}$ & $7.5 \mathrm{a}$ & $36.9 \mathrm{a}$ & $22.3 \mathrm{a}$ & $33.4 \mathrm{a}$ \\
\hline $\operatorname{LSD}(P=0.05)$ & 2.7 & 8.2 & 7.5 & 7.7 & 2.5 & 7.8 & 7.0 & 7.5 \\
\hline \multicolumn{9}{|l|}{ Phaeomoniella chlamydospora } \\
\hline & \multicolumn{4}{|c|}{ 2-year-old plants } & \multicolumn{4}{|c|}{ 3-year-old plants } \\
\hline & \multicolumn{2}{|c|}{ DI $(\%)$} & \multicolumn{2}{|c|}{ DS (\%) } & \multicolumn{2}{|r|}{ DI $(\%)$} & \multicolumn{2}{|c|}{ DS (\%) } \\
\hline & Roots & Basal ends & Roots & Basal ends & Roots & Basal ends & Roots & Basal ends \\
\hline T1. Streptomyces sp. E1 + R4 & $6.3 \mathrm{a}$ & $11.3 \mathrm{a}$ & $10.0 \mathrm{ab}$ & $27.6 \mathrm{a}$ & $7.5 \mathrm{a}$ & $15.6 \mathrm{a}$ & $9.2 \mathrm{a}$ & $28.2 \mathrm{ab}$ \\
\hline T2. Trichoderma koningii TK7 & $6.3 \mathrm{a}$ & $18.8 \mathrm{a}$ & $10.6 \mathrm{ab}$ & $25.0 \mathrm{a}$ & $8.1 \mathrm{a}$ & $18.8 \mathrm{a}$ & $14.2 \mathrm{a}$ & $35.0 \mathrm{a}$ \\
\hline T3. Trichoderma atroviride $\mathrm{SC} 1$ & $7.5 \mathrm{a}$ & $14.4 \mathrm{a}$ & $14.8 \mathrm{ab}$ & $29.8 \mathrm{a}$ & $8.1 \mathrm{a}$ & $6.3 \mathrm{~b}$ & $15.8 \mathrm{a}$ & $15.0 \mathrm{~b}$ \\
\hline T4. Pseudomonas fluorescens + Bacillus atrophaeus & $6.3 \mathrm{a}$ & $17.5 \mathrm{a}$ & $13.3 \mathrm{ab}$ & $28.5 \mathrm{a}$ & $7.5 \mathrm{a}$ & $17.5 \mathrm{a}$ & $11.7 \mathrm{a}$ & $38.7 \mathrm{a}$ \\
\hline T5. Pythium oligandrum Po37 & $1.9 \mathrm{~b}$ & $22.5 \mathrm{a}$ & $7.5 \mathrm{~b}$ & $20.9 \mathrm{a}$ & $0.6 \mathrm{~b}$ & $22.5 \mathrm{a}$ & $12.5 \mathrm{a}$ & $31.0 \mathrm{a}$ \\
\hline Control (C) & $9.4 \mathrm{a}$ & $20.6 \mathrm{a}$ & $15.4 \mathrm{a}$ & $28.3 \mathrm{a}$ & $9.4 \mathrm{a}$ & $20.6 \mathrm{a}$ & $10.6 \mathrm{a}$ & $34.6 \mathrm{a}$ \\
\hline $\operatorname{LSD}(P=0.05)$ & 3.1 & 5.5 & 3.6 & 7.4 & 3.3 & 3.8 & 3.8 & 7.1 \\
\hline \multicolumn{9}{|l|}{ Phaeoacremonium minimum } \\
\hline & \multicolumn{4}{|c|}{ 2-year-old plants } & \multicolumn{4}{|c|}{ 3-year-old plants } \\
\hline & \multicolumn{2}{|c|}{ DI $(\%)$} & \multicolumn{2}{|c|}{ DS (\%) } & \multicolumn{2}{|c|}{ DI $(\%)$} & \multicolumn{2}{|c|}{ DS (\%) } \\
\hline & Roots & Basal ends & Roots & Basal ends & Roots & Basal ends & Roots & Basal ends \\
\hline T1. Streptomyces sp. E1 + R4 & $4.4 \mathrm{ab}$ & $11.3 \mathrm{a}$ & $16.3 \mathrm{a}$ & $15.1 \mathrm{a}$ & $4.0 \mathrm{a}$ & $15.0 \mathrm{a}$ & $13.8 \mathrm{a}$ & $21.0 \mathrm{a}$ \\
\hline T2. Trichoderma koningii TK7 & $3.1 \mathrm{~b}$ & $16.9 \mathrm{a}$ & $18.8 \mathrm{a}$ & $13.6 \mathrm{a}$ & $4.1 \mathrm{a}$ & $16.5 \mathrm{a}$ & $2.5 \mathrm{~b}$ & $9.5 \mathrm{~b}$ \\
\hline T3. Trichoderma atroviride SC1 & $5.0 \mathrm{ab}$ & $11.3 \mathrm{a}$ & $7.1 \mathrm{~b}$ & $11.8 \mathrm{a}$ & $3.9 \mathrm{a}$ & $14.7 \mathrm{a}$ & $3.8 \mathrm{~b}$ & $22.4 \mathrm{a}$ \\
\hline T4. Pseudomonas fluorescens + Bacillus atrophaeus & $3.1 \mathrm{~b}$ & $17.5 \mathrm{a}$ & $23.8 \mathrm{a}$ & $12.8 \mathrm{a}$ & $4.3 \mathrm{a}$ & $15.1 \mathrm{a}$ & $15.0 \mathrm{a}$ & $17.7 \mathrm{ab}$ \\
\hline T5. Pythium oligandrum Po37 & $3.8 \mathrm{ab}$ & $16.9 \mathrm{a}$ & $16.3 \mathrm{a}$ & $10.3 \mathrm{a}$ & $4.0 \mathrm{a}$ & $15.8 \mathrm{a}$ & $12.5 \mathrm{a}$ & $18.3 \mathrm{ab}$ \\
\hline Control $(\mathrm{C})$ & $5.6 \mathrm{a}$ & $16.9 \mathrm{a}$ & $21.7 \mathrm{a}$ & $17.0 \mathrm{a}$ & $4.0 \mathrm{a}$ & $17.2 \mathrm{a}$ & $12.5 \mathrm{a}$ & $19.9 \mathrm{ab}$ \\
\hline $\operatorname{LSD}(P=0.05)$ & 2.3 & 3.6 & 3.5 & 3.3 & 2.7 & 3.1 & 3.6 & 3.5 \\
\hline
\end{tabular}

a At each plant part, percentages of disease incidence (DI) and disease severity (DS) are the mean of 160 plants analyzed (40 plants per replicate). Values in the same column followed by the same letter do not differ significantly $(P=0.05)$. 
Table 3. Mean disease incidence (DI) and severity (DS) of the most prevalent black-foot disease pathogens isolated from the roots and basal ends of rootstock of 2-yearold and 3-year-old grafted plants subjected to various treatments prior to planting in two fields in Logroño (La Rioja).

\begin{tabular}{|c|c|c|c|c|c|c|c|c|}
\hline \multicolumn{9}{|l|}{ Dactylonectria torresensis } \\
\hline & \multicolumn{4}{|c|}{ 2-year-old plants } & \multicolumn{4}{|c|}{ 3-year-old plants } \\
\hline & \multicolumn{2}{|c|}{$\mathrm{DI}(\%)^{\mathrm{a}}$} & \multicolumn{2}{|c|}{$\mathrm{DS}(\%)^{\mathrm{a}}$} & \multicolumn{2}{|c|}{ DI $(\%)$} & \multicolumn{2}{|c|}{ DS (\%) } \\
\hline & Roots & Basal ends & Roots & Basal ends & Roots & Basal ends & Roots & Basal ends \\
\hline T1. Streptomyces sp. E1 + R4 & $31.3 \mathrm{a}$ & $6.3 \mathrm{~b}$ & $20.5 \mathrm{a}$ & $3.8 \mathrm{~b}$ & $21.3 \mathrm{a}$ & $1.3 \mathrm{~b}$ & $12.3 \mathrm{a}$ & $20.0 \mathrm{a}$ \\
\hline T2. Trichoderma koningii TK7 & $30.0 \mathrm{a}$ & $6.3 \mathrm{~b}$ & $15.3 \mathrm{a}$ & $22.1 \mathrm{a}$ & $26.9 \mathrm{a}$ & $10.0 \mathrm{a}$ & $13.5 \mathrm{a}$ & $19.7 \mathrm{a}$ \\
\hline T3. Trichoderma atroviride SC1 & $25.0 \mathrm{a}$ & $5.0 \mathrm{~b}$ & $23.0 \mathrm{a}$ & $17.5 \mathrm{a}$ & $21.9 \mathrm{a}$ & $14.4 \mathrm{a}$ & $13.8 \mathrm{a}$ & $16.7 \mathrm{a}$ \\
\hline T4. Pseudomonas fluorescens + Bacillus atrophaeus & $31.3 \mathrm{a}$ & $4.4 \mathrm{~b}$ & $18.5 \mathrm{a}$ & $22.5 \mathrm{a}$ & $26.9 \mathrm{a}$ & $10.0 \mathrm{a}$ & $10.8 \mathrm{a}$ & $18.3 \mathrm{a}$ \\
\hline T5. Pythium oligandrum Po37 & $25.0 \mathrm{a}$ & $3.8 \mathrm{~b}$ & $17.6 \mathrm{a}$ & $28.3 \mathrm{a}$ & $30.6 \mathrm{a}$ & $12.5 \mathrm{a}$ & $10.0 \mathrm{a}$ & $20.5 \mathrm{a}$ \\
\hline Control (C) & $25.0 \mathrm{a}$ & $14.4 \mathrm{a}$ & $20.6 \mathrm{a}$ & $18.1 \mathrm{a}$ & $20.6 \mathrm{a}$ & $11.9 \mathrm{a}$ & $11.5 \mathrm{a}$ & $19.9 \mathrm{a}$ \\
\hline $\operatorname{LSD}(P=0.05)$ & 6.6 & 6.2 & 6.0 & 6.5 & 5.8 & 3.8 & 3.2 & 3.5 \\
\hline \multicolumn{9}{|l|}{ Dactylonectria macrodidyma } \\
\hline & \multicolumn{4}{|c|}{ 2-year-old plants } & \multicolumn{4}{|c|}{ 3-year-old plants } \\
\hline & \multicolumn{2}{|c|}{ DI $(\%)$} & \multicolumn{2}{|c|}{ DS $(\%)$} & \multicolumn{2}{|c|}{ DI $(\%)$} & \multicolumn{2}{|c|}{ DS $(\%)$} \\
\hline & Roots & Basal ends & Roots & Basal ends & Roots & Basal ends & Roots & Basal ends \\
\hline T1. Streptomyces sp. E1 + R4 & $8.8 \mathrm{~b}$ & $2.5 \mathrm{~b}$ & $16.3 \mathrm{a}$ & $0 \mathrm{~b}$ & $3.6 \mathrm{~b}$ & $3.8 \mathrm{a}$ & $5.8 \mathrm{a}$ & $0 \mathrm{~b}$ \\
\hline T2. Trichoderma koningii TK7 & $9.4 \mathrm{ab}$ & $3.1 \mathrm{~b}$ & $17.8 \mathrm{a}$ & $3.8 \mathrm{ab}$ & $10.6 \mathrm{a}$ & $3.1 \mathrm{a}$ & $4.8 \mathrm{a}$ & $3.3 \mathrm{ab}$ \\
\hline T3. Trichoderma atroviride SC1 & $11.3 \mathrm{ab}$ & $1.3 \mathrm{~b}$ & $18.8 \mathrm{a}$ & $2.5 \mathrm{ab}$ & $7.5 \mathrm{a}$ & $3.8 \mathrm{a}$ & $4.1 \mathrm{a}$ & $0 \mathrm{~b}$ \\
\hline T4. Pseudomonas fluorescens + Bacillus atrophaeus & $13.8 \mathrm{ab}$ & $1.3 \mathrm{~b}$ & $18.5 \mathrm{a}$ & $2.5 \mathrm{ab}$ & $10.0 \mathrm{a}$ & $4.4 \mathrm{a}$ & $5.1 \mathrm{a}$ & $2.5 \mathrm{ab}$ \\
\hline T5. Pythium oligandrum Po37 & $16.9 \mathrm{ab}$ & $3.8 \mathrm{~b}$ & $11.8 \mathrm{a}$ & $1.7 \mathrm{ab}$ & $9.4 \mathrm{a}$ & $3.1 \mathrm{a}$ & $4.2 \mathrm{a}$ & $5.0 \mathrm{ab}$ \\
\hline Control (C) & $16.3 \mathrm{a}$ & $10.0 \mathrm{a}$ & $14.8 \mathrm{a}$ & $6.1 \mathrm{a}$ & $8.8 \mathrm{a}$ & $3.8 \mathrm{a}$ & $4.0 \mathrm{a}$ & $6.3 \mathrm{a}$ \\
\hline $\operatorname{LSD}(P=0.05)$ & 3.6 & 3.3 & 3.7 & 2.3 & 3.0 & 2.5 & 2.6 & 2.3 \\
\hline \multicolumn{9}{|l|}{ Ilyonectria liriodendri } \\
\hline & \multicolumn{4}{|c|}{ 2-year-old plants } & \multicolumn{4}{|c|}{ 3-year-old plants } \\
\hline & \multicolumn{2}{|c|}{ DI $(\%)$} & \multicolumn{2}{|c|}{ DS (\%) } & \multicolumn{2}{|c|}{ DI $(\%)$} & \multicolumn{2}{|c|}{ DS (\%) } \\
\hline & Roots & Basal ends & Roots & Basal ends & Roots & Basal ends & Roots & Basal ends \\
\hline T1. Streptomyces sp. E1 + R4 & $3.8 \mathrm{a}$ & $0.6 \mathrm{a}$ & $11.7 \mathrm{a}$ & $0 \mathrm{~b}$ & $3.8 \mathrm{a}$ & $0.6 \mathrm{a}$ & $30.8 \mathrm{a}$ & $5.0 \mathrm{a}$ \\
\hline T2. Trichoderma koningii TK7 & $2.5 \mathrm{a}$ & $1.9 \mathrm{a}$ & $12.5 \mathrm{a}$ & $6.3 \mathrm{ab}$ & $3.1 \mathrm{a}$ & $0.6 \mathrm{a}$ & $32.5 \mathrm{a}$ & $2.5 \mathrm{a}$ \\
\hline T3. Trichoderma atroviride SC1 & $4.4 \mathrm{a}$ & $1.9 \mathrm{a}$ & $12.5 \mathrm{a}$ & $7.5 \mathrm{a}$ & $3.8 \mathrm{a}$ & $0.6 \mathrm{a}$ & $30.0 \mathrm{a}$ & $5.0 \mathrm{a}$ \\
\hline T4. Pseudomonas fluorescens + Bacillus atrophaeus & $2.5 \mathrm{a}$ & $0.6 \mathrm{a}$ & $16.3 \mathrm{a}$ & $2.5 \mathrm{ab}$ & $3.1 \mathrm{a}$ & $1.3 \mathrm{a}$ & $36.3 \mathrm{a}$ & $5.0 \mathrm{a}$ \\
\hline T5. Pythium oligandrum Po37 & $2.5 \mathrm{a}$ & $1.3 \mathrm{a}$ & $12.5 \mathrm{a}$ & $7.5 \mathrm{a}$ & $3.1 \mathrm{a}$ & $0.6 \mathrm{a}$ & $28.8 \mathrm{a}$ & $5.0 \mathrm{a}$ \\
\hline Control (C) & $3.8 \mathrm{a}$ & $0.6 \mathrm{a}$ & $10.0 \mathrm{a}$ & $2.5 \mathrm{ab}$ & $2.5 \mathrm{a}$ & $0.6 \mathrm{a}$ & $30.0 \mathrm{a}$ & $5.0 \mathrm{a}$ \\
\hline $\operatorname{LSD}(P=0.05)$ & 2.5 & 2.4 & 3.1 & 2.9 & 2.5 & 2.2 & 7.1 & 2.5 \\
\hline
\end{tabular}

a At each plant part, percentages of disease incidence (DI) and disease severity (DS) are the mean of 160 plants analyzed (40 plants per replicate). Values in the same column followed by the same letter do not differ significantly $(P=0.05)$. 
Table 4. Pathogen reduction achieved by BCA treatments in the 3-year-old plants, associated with Petri and black-foot disease.

\begin{tabular}{|c|c|c|c|}
\hline Petri disease & & & \\
\hline Plant part & Biocontrol agent & Pathogen & Reduction $^{\mathrm{a}}$ \\
\hline \multirow{3}{*}{ Roots } & Pythium oligandrum Po37 & Pa. chlamydospora & $93.6 \%\left(\mathrm{DI}^{\mathrm{b}}\right)$ \\
\hline & Trichoderma koningii TK7 & Pm. minimum & $80 \%\left(\mathrm{DS}^{\mathrm{c}}\right)$ \\
\hline & Trichoderma atroviride $\mathrm{SC1}$ & Pm. minimum & $69.6 \%(\mathrm{DS})$ \\
\hline \multirow[t]{2}{*}{ Basal ends } & Trichoderma atroviride SC1 & Pa. chlamydospora & $\begin{array}{l}69.4 \% \text { (DI) } \\
56.6 \% \text { (DS) }\end{array}$ \\
\hline & Trichoderma koningii TK7 & Pm. minimum & $52.3 \%(\mathrm{DS})$ \\
\hline \multicolumn{4}{|l|}{ Black-foot disease } \\
\hline \multirow{3}{*}{ Basal ends } & Streptomyces sp. E1 + R4 & D. torresensis & $89.1 \%(\mathrm{DI})$ \\
\hline & Streptomyces sp. E1 + R4 & D. macrodidyma & $100 \%(\mathrm{DS})$ \\
\hline & Trichoderma atroviride SC1 & D. macrodidyma & $100 \%(\mathrm{DS})$ \\
\hline
\end{tabular}

${ }^{a}$ The percentage of reduction $(\mathrm{PR})$ of the pathogen detection at each plant part was calculated as $\mathrm{PR}=100(\mathrm{PC}-\mathrm{PT}) / \mathrm{PC}$, where $\mathrm{PC}$ is the mean pathogen incidence or severity in the control and PT is the mean pathogen incidence or severity in the biocontrol agent treatment.

${ }^{\mathrm{b}}$ Disease incidence

${ }^{\mathrm{c}}$ Disease severity 